\title{
ANALISIS RAGAM BAHASA ISTILAH DALAM IKLAN PARIWISATA DI MEDIA DIGITAL PADA MASA PANDEMI COVID-19
}

\author{
Ni Putu Cahyani Putri Utami \\ Email: mscahyaniputri@unmas.ac.id \\ Universitas Mahasaraswati Denpasar
}

\begin{abstract}
This study aimed ro describe and determine the characteristic patterns and the word formation process of various language terms used in tourism advertisements on digital media during the COVID-19 pandemic. There are several new terms that are widely used by people all over the globe, and tourism adevertisements are no excpetion. This study used descriptive qualitative method. The data were taken from advertisements found on social media Facebook and Instagram. The thoery used in this research is the theory of language style proposed by Chaer \& Agustina (2010) and theory of word formation process by Chaer (2008). It can be concluded that: (1) the characteristic pattern of the variety of languages used in tourism advertisements on social media Facebook and Instagram during the COVID-19 pandemic is a variety of non-formal languages, and (2) the variety of terms used tourism advertisements on social media Facebook and Instagram during the COVID-19 pandemic are formed from blending, abbreviations and compounding.
\end{abstract}

Keywords: Language Varieties, Terms, Advertisement, COVID-19

\section{Abstrak}

Penelitian ini bertujuan untuk mendeskripsikan dan mengetahui pola karakteristik serta proses pembentukan berbagai ragam bahasa istilah yang digunakan dalam iklan pariwisata di media digital selama masa pandemi COVID-19. Ada beberapa istilah baru yang banyak digunakan oleh orang-orang di seluruh dunia, tidak terkecuali pada iklan pariwisata. Penelitian ini menggunakan metode deskriptif kualitatif. Data diambil dari iklan yang terdapat di media digital. Teori yang digunakan dalam penelitian ini adalah teori gaya bahasa yang dikemukakan oleh Chaer \& Agustina (2010) dan teori proses pembentukan kata oleh Katamba \& Chaer (2008). Berdasarkan hasil penelitian, dapat disimpulkan bahwa: (1) pola karakteristik ragam bahasa yang digunakan dalam iklan pariwisata di media digital pasa masa pandemi COVID-19 adalah ragam bahasa 
nonformal, dan (2) ragam istilah yang digunakan terbentuk dari proses blending, singkatan dan compounding.

Kata Kunci: Ragam Bahasa, Istilah, Iklan, COVID-19

\section{Pendahuluan}

Bahasa dinilai mampu memberikan andil besar bagi perkembangan peradaban manusia, sehingga bahasa dan manusia merupakan dua hal yang tidak dapat dipisahkan. Bahasa secara luas dapat diartikan sebagai suatu pengungkapan seseorang baik dalam simbol maupun kata. Chaer \& Agustina (2010) menjelaskan bahwa fungsi utama bahasa adalah sebagai media komunikasi. Hal ini sejalan dengan Suwarna (2002) yang menyatakan bahwa bahasa merupakan media komunikasi utama sebagai makhluk sosial untuk bersosialisasi. Rahardi (2006) menambahkan bahwa bahasa berfungsi sebagai alat komunikasi yang digunakan untuk menyatakan ekspresi diri dari segala hal yang tersirat dalam pikiran maupun perasaan. Fungsi dasar bahasa adalah sebagai alat komunikasi masyarakat. Bahasa selalu dihubungkan dengan kehidupan sosial sehari-hari karena melalui bahasa, manusia mampu menyampaikan ide, mengungkapkan perasaan dan mengembangkan pemikiran.

Bahasa, selain sebagai media komunikasi, juga memiliki peran penting dalam manajemen pemasaran. Dalam bidang pemasaran, bahasa digunakan sebagai media promosi dalam menawarkan suatu produk atau jasa kepada pembeli. Ragam bahasa dalam media promosi sangat beraneka ragam. Penggunaan istilah yang menarik dalam suatu iklan mampu menarik perhatian, meningkatkan imajinasi dan memudahkan ingatan pembaca (Pratiwi, 2016). Bahasa iklan merupakan bahasa yang kaya akan gaya maupun pilihan kata. Gaya bahasa iklan menggunakan bahasa secara khusus dan senang bermain dengan pemilihan kata-kata yang menarik bahkan memanipulasi. Salah satu media promosi yang digunakan dewasa 
ini adalah media sosial, seperti Facebook dan Instagram. Promosi melalui media sosial mampu dengan mudah menjangkau wisatawan.

Bahasa berkaitan erat dengan budaya maupun suatu generasi. Perkembangan bahasa mengikuti arus perkembangan suatu zaman. Perkembangan bahasa berhubungan erat dengan tingkat keberhasilan dalam menciptakan dan menggunakan kosakata serta istilah-istilah baru dengan baik. Tidak jarang istilah-istilah yang digunakan dapat dipahami secara berbeda sehingga akan berpengaruh pada pesan yang ingin disampaikan dan perkembangan bahasa selanjutnya. Bahasa mampu berperan dalam memfasilitasi komunikasi dalam mempelajari dan memaknai sesuatu dalam situasi dan kondisi tertentu. Bahasa juga mampu mewakili suatu kondisi lingkungan masyarakat dari satu generasi.

Sejak Badan Kesehatan Dunia (WHO) menetapkan wabah virus COVID-19 sebagai pandemi global, sektor pariwisata mengalami penurunan yang signifikan. Seperti diketahui, pariwisata merupakan sektor yang paling terdampak pandemi COVID-19 dan perekonomian Bali, yang bergantung pada sektor pariwisata, tekontraksi hingga minus 9,13\% sepanjang tahun 2020. Seluruh destinasi wisata, hotel dan akomodasi lainnya ditutup sementara karena adanya pembatasan perjalanan dan kegiatan di seluruh dunia yang perlu dilakukan dalam mencegah penularan virus ini. Setelah selama lebih dari 9 bulan, pariwisata Bali kembali dibuka. Namun, dengan memperketat penerapan protokol kesehatan dan membatasi jumlah kunjungan wisatawan.

Sejumlah hotel, villa dan usaha industri pariwisata lainnya mulai melakukan promosi dengan cara memasang beberapa iklan melalui berbagai media sosial. Dalam beberapa iklan tersebut, terselip beberapa istilah baru yang dewasa ini menjadi tren diantara para pengguna bahasa dan kini penggunaannya telah beredar luas. Selain istilah-istilah resmi medis, yang kini menjadi populer di media massa dan telah menjadi istilah 
umum, terdapat beberapa istilah-istilah baru yang secara tidak terduga berasal dari masyarakat dan digunakan secara luas oleh masyarakat. Fenomena bahasa baru ini muncul dikarenakan istilah-istilah tersebut dibutuhkan oleh masyarakat dalam berkomunikasi, berinteraksi, menyampaikan ide, pemikiran dan perasaan, serta mampu menggambarkan situasi kehidupan masyarakat selama masa pandemi COVID-19 ini.

Thorne \& Lantolf (2006) menyatakan bahwa kemunculan istilahistilah baru pada suatu zaman, generasi atau kondisi merupakan fenomena kebahasaan yang wajar terjadi karena manusia membutuhkan kosakata baru untuk dapat mengungkapkan pemikiran dan perasaannya mengenai peristiwa yang sedang terjadi. Penggunaan istilah-istilah baru tersebut harus dipahami secara cermat untuk dapat digunakan secara tepat sehingga masyarakat dapat mengerti makna dari istilah tersebut. Munculnya fenomena kebahasaan pada masa pandemi COVID-19 menjadi acuan penelitian ini dilaksanakan. Berdasarkan pemaparan latar belakang tersebut, penelitian ini bertujuan untuk mengkaji pola karakteristik dan proses pembentukan ragam bahasa istilah dalam iklan pariwisata di media digital pada masa pandemi COVID-19.

\section{Konsep dan Teori}

Konsep dan teori yang digunakan mencakup batasan terminologi teknis yang digunakan dalam penelitian ini terangkum sebagai berikut. 2.1 Ragam Bahasa

Ragam bahasa, ata variasi bahasa, dapat diklasifikasikan berdasarkan adanya keragaman sosial dan fungsi kegiatan dalam masyarakat sosial. Variasi bahasa terjadi bukan hanya disebabkan oleh penutur bahasa yang bersifat heterogen namun juga dapat disebabkan oleh adanya variasi kegiatan interaksi sosial yang dilakukan serta dapat juga 
dipenagruhi oleh faktor situasional. Nababan (1984) mendefinisikan ragam bahasa sebagai variasi atau perbedaan bahasa, baik bentuk maupun makna, berdasarkan perbedaan daerah, kelompok sosial yang beragam, keadaan atau status sosial yang berbeda, situasi berbahasa, tingkat formalitas dan generasi yang berbeda. Kridalaksana (1993) lebih jauh menjelaskan bahwa ragam bahasa merupakan variasi bahasa menurut pemakaian, topik yang dibicarakan, hubungan antar pembicara atau penutur, lawan bicara, orang yang dibicarakan serta media pembicaraan. Sehingga dapat disimpulkan bahwa ragam bahasa merupakan variasi bahasa yang digunakan sesuai dengan kebutuhan dan keperluan dalam berkomunikasi.

Bahasa, dalam pemakaiannya, memiliki bermacam-macam ragam dari segi tipe, sumber, level, model, dan jenis variasi bahasa. Chaer (2010) menyatakan bahwa ragam bahasa dapat dilihat melalui dua sudut pandang yang berbeda, yakni: (1) ragam bahasa terjadi akibat dari adanya keragaman sosial penutur bahasa dan keragaman fungsi bahasa, dan (2) ragam bahasa terjadi untuk memenuhi fungsinya sebagai alat interaksi dan besosialisasi dalam kegiatan masyarakat yang beraneka ragam. Ragam bahasa juga dapat disebut sebagai gaya bahasa perseorangan karena pemilihannya bergantung pada pemakainya. Menurut Alwi, dkk. (2003) pemilihan suatu gaya bahasa akan bergantung pada sikap penutur terhadap lawan bicara. Keragaman ini akan semakin bertambah jika ragam bahasa tersebut digunakan oleh penutur dalam jangakaun wilayah yang luas.

\subsection{Bahasa Iklan}

Bahasa iklan memiliki ciri yang membuat bahasa tersebut begitu berbeda dibandingkan dengan penggunaan bahasa untuk kepentingan lainnya. Bahasa iklan, atau bahasa periklanan, mengacu pada bahasa yang digunakan dalam sebuah iklan untuk memfasilitasi pemahaman konsumen 
mengenai suatu produk atau jasa yang ditawarkan oleh suatu perusahaan (Kriyantono, 2008). Penggunaan bahasa dalam sebuah iklan dimaksudkan untuk dapat memancing respon atau tanggapan dari khalayak sasaran, sehingga bahasa iklan wajib memiliki kemampuan untuk menarik minat, menggugah, mengidentifikasi produk atau jasa, serta mengkomunikasikan pesan kepada khalayak secara kooperatif. Selain ditujukan untuk mendapatkan perhatian, bahasa iklan juga harus dengan mudah dipahami oleh khalayak, sederhana dan bahasa yang digunakan adalah bahasa positif bukan bahasa negatif.

Kata yang digunakan dalam bahasa iklan harus singkat, jelas, komunikatif, bersahabat dan mampu menonjolkan atribut-atribut penting dari sebuah produk, jasa atau entitas yang diiklankan. Menurut Goddard (2002) bahasa iklan memiliki beberapa prinsip yakni: 1) bahasa iklan merupakan sebuah pernyataan jujur, bertanggungjawab, serta tidak bertentangan dengan aturan atau hukum yang berlaku di masyarakat, 2) bahasa iklan merupakan sebuah penyataan yang dibuat bukan untuk menyinggung perasaan siapapun, merendahkan suatu golongan, negara, agama, adat dan budaya, suku maupun keyakinan, serta 3) bahasa iklan merupakan sebuah pernyataan yang disusun dengan asas persaingan yang sehat.

Secara umum, sebuah iklan memadukan lebih dari satu jenis bahasa, yakni bahasa verbal yang berupa kata, frasa atau kalimat dan bahasa nonverbal atau paralinguistik yang dapat berupa ekpresi wajah, gerak tubuh, kualitas suara atau gambar dan ditujukan untuk melengkapi bahasa verbal. Bahasa iklan yang baik adalah bahasa persuasif yakni memiliki efek presuasif terhadap khalayak sasaran. Bahasa persuasif menekankan pada pemakaian cara yang paling efektif untuk mempengaruhi sikap dan perilaku khalayak sasaran. Penyampaian pesan 
pada sebuah iklan umumnya menggunakan kata sifat, gaya bahasa hiperbola, frasa, kalimat pendek, eufinisme, bahasa istilah dan bahasa kias. Berdasarkan penjabaran tersebut, dapat disimpulkan bahwa inovasi bahasa iklan sangat dibutuhkan mengingat perubahan dan kondisi sosial terjadi begitu cepat dan mampu mempengaruhi bahasa yang digunakan. Pengiklan sebaiknya mampu beradaptasi atau menyesuaikan bahasa iklan yang digunakan agar sesuai dengan perubahan dan tren yang sedang terjadi di masyarakat. Ragam bahasa inilah yang akan membentuk suatu produk atau jasa lebih dikenal daripada produk kompetitor lainnya.

\subsection{Istilah}

Istilah, yang juga dapat disebut sebagai terminologi atau term, dapat diartikan sebagai lambang, sebutan atau ungkapan khusus yang mampu mengungkapkan konsep termaksud dan tidak menyimpang dari makna (Suwardjono, 1988). Wiratno (2018) lebih jauh mendefinisikan istilah sebagai suatu kata atau kombinasi dari dua kata atau lebih yang memiliki fungsi sebagai pengungkap sebuah nama, proses, konsep, ide, sifat atau keadaan dan kondisi pada bidang tertentu, seperti ilmu pengetahuan, teknologi, medis, seni dan lain sebagainya. Berdasarkan pengertian tersebut, dapat disimpulkan bahwa istilah merupakan sebutan atau ungkapan yang mampu mengungkapkan konsep secara umum maupun secara khusus dan tidak menyimpang dari makna.

Menurut batas penggunaan, istilah dapat dibagi menjadi dua jenis, yakni istilah khusus dan istilah umum. Istilah khusus adalah kata-kata yang dalam penggunaannya terbatas pada bidang tertentu, sedangkan istilah umum merupakan istilah yang telah digunakan dan telah dipahami artinya secara luas. Berbeda dengan istilah khusus yang tidak diketahui dan dipahami oleh semua orang, istilah umum digunakan oleh siapa saja karena tidak diperlukan suatu pengetahuan khusus dalam memahami maknanya. 
Tidak semua kata dalam suatu bahasa dapat disebut istilah. Terdapat beberapa syarat atau kaidah yang menjadikan suatu kata menjadi sebuah istilah. Suatu kata dapat dijadikan sebuah istilah jika kata tersebut mampu dengan tepat mengungkapkan makna, proses, keadaan atau sifat yang dimaksudkan. Selain itu, istilah juga dapat berupa kata umum yang diberi makna baru atau khusus dengan mempersempit atau meluaskan makna kata asalnya.

Proses pembentukan sebuah istilah di Indonesia dapat melalui berbagai cara. Suwardjono (2004) menjelaskan bahwa suatu istilah dapat berasal dari kata berbahasa Indoenesia jika kata tersebut mampu dengan tepat mengungkapkan konsep, proses, keadaan atau sifat yang dimaksudkan dalam bahasa Indonesia. Kedua, jika dalam bahasa Indonesia tidak ditemukan istilah yang tepat, maka istilah dapat dicari atau dibentuk dari bahasa serumpun. Ketiga, jika baik dari bahasa Indonesia maupun bahasa serumpun tidak juga ditemukan istilah yang tepat, maka bahasa asing dapat dijadikan sebagai sumber pembentukan istilah baru sebagai suatu ragam bahasa istilah. Proses tersebut dikenal dengan istilah borrowing dan menghasilkan kata serapan. Proses penyerapan bahasa asing dilakukan dengan atau tanpa pengubahan yang berupa penyesuaian ejaan dan lafal. Berikut ini dijabarkan beberapa contoh istilah dari bahasa asing yang juga digunakan dalam istilah Indonesia.

Tabel 1. Penyerapan Istilah Asing dalam Istilah Bahasa Indonesia

\begin{tabular}{|c|c|c|l|}
\hline No. & Istilah Asing & $\begin{array}{c}\text { Istilah Indonesia } \\
\text { yang dianjurkan }\end{array}$ & $\begin{array}{c}\text { Istilah Indonesia } \\
\text { yang tidak } \\
\text { dianjurkan }\end{array}$ \\
\hline 1. & Chemistry & Kimia & Ilmu Urai \\
\hline 2. & Horizon & Horizon & $\begin{array}{l}\text { Kakilangit, Ufuk } \\
\text { Cakrawala }\end{array}$ \\
\hline 3. & Marathon & Maraton & Lari Jarak Jauh \\
\hline 4. & Amputation & Amputasi & $\begin{array}{l}\text { Pemotongan } \\
\text { Anggota Badan }\end{array}$ \\
\hline
\end{tabular}


Istilah baru yang berasal dari bahasa asing dapat dibentuk dengan menerjemahkan kata asing tersebut secara langsung, seperti istilah network yang berarti jaringan dan istilah balance budget yang berarti anggaran berimbang. Namun tidak semua istilah dari bahasa asing dapat diserap dan diterjemahkan secara langsung kedalam bahasa Indonesia. Istilah yang diambil dari bahasa asing dapat berupa bentuk dasar atau bentuk turunan. Pemilihan bentuk tersebut dapat dilakukan dengan mempertimbangkan konteks situasi dan ikatan kalimat, kemudahan belajar bahasa, dan kepraktisan. Demi kemudahan pengalihan antarbahasa, penyerapan istilah asing dilakukan dengan menggunakan proses penyerapan yang bersifat internasional, yakni bentuk istilah yang dilazimkan oleh para ahli dalam bidangnya. Penulisan istilah asing tersebut dilakukan dengan mengutamakan ejaannya dalam bahasa sumber tanpa mengabaikan segi lafalnya (Suwardjono, 2004). Dengan kata lain, masuknya istilah dalam bahasa asing mampu secara langsung dilakukan melalui proses penyerapan tanpa melalui proses penerjemahan atau pengubahan dan hanya dilakukan penyesuaian berupa ejaan dan lafal dalam bahasa Indonesia.

\subsection{Proses Pembentukan Kata}

Setiap bahasa memiliki cara-cara tersendiri dalam proses pembentukan. Proses pembentukan kata merupakan suatu proses formasi kata leksikal yang terbentuk dari gabungan suatu elemen morfologi (Huddleston \& Pullum, 2002). Lebih jauh Chaer (2008) menjelaskan bahwa proses pembentukan kata didefinisikan sebagai proses pembentukan kata dari bentuk dasar dengan menambahkan afiks (afiksasi), pengulangan (reduplikasi), penggabungan (komposisi), pemendekan (akronimisasi) dan perubahan status (konversi). Berdasarkan penjabaran tersebut, dapat disimpulkan bahwa proses pembentukan kata merupakan proses pembentukan kata-kata dari satuan lain yang merupakan bentuk 
dasarnya dan menghasilkan kata bentukan baru yang berbeda secara bentuk, gramatikal, fungsi maupun makna.

\subsection{Teori Ragam Bahasa}

Menurut Holmes (2001) ragam bahasa merupakan bentuk variasi kata yang berubah-ubah menurut kegunaan dan penggunaannya, tempat digunakan serta siapa penutur dan mitra tuturnya. Oktavia (2018) menyatakan bahwa ragam bahasa merupakan salah satu jenis variasi bahasa yang pemakaiannya disesuaikan dengan fungsi bahasa dan situasinnya tanpa mengabaikan kaidah-kaidah pokok bahasa yang digunakan. Ragam bahasa terjadi berdasarkan keperluan atau penggunaan dalam suatu bidang ilmu tertentu, gaya bahasa, tingkat keformalan, serta sarana atau media penggunaan. Ragam bahasa pada suatu bidang atau ilmu akan paling tampak cirinya pada pemakaian dan penggunaan kosakata karena setiap bidang ilmu memiliki sejumlah kosakata khusus yang tidak digunakan dalam bidang ilmu lainnya. Namun dalam kajian ilmu linguistik, ragam bahasa dikaji dalam tataran proses pembentukan kata (morfologis) dan penggunaannya dalam tataran kalimat (sintaksis).

Menurut para ahli bahasa, ragam bahasa dapat diklasifikasikan menjadi beberapa bagian berbeda. Soeparno (2002) menyatakan bahwa ragam bahasa dapat disebabkan oleh faktor-faktor tertentu, seperti faktor geografis, kedudukan atau status sosial, situasi berbahasa, waktu, gaya, kultural dan individual. Berdasarkan beberapa faktor tersebut, Chaer \& Agustina (2010) menjelaskan bahwa ragam bahasa dapat dibedakan menjadi beberapa kelompok, yakni: 1) ragam bahasa menurut penutur, yakni ragam bahasa perseorangan (idiolek), ragam bahasa sekelompok anggota masyarakat tertentu (dialek) dan ragam bahasa yang digunakan oleh sekelompok anggota masyarakat dari golongan sosial tertentu (sosiolek), 2) ragam bahasa menurut topik pembicaraan, yakni ragam 
fungsional, ragam sastra, ragam politik dan hukum serta ragam jurnalistik, dan 3) ragam bahasa menurut situasi dan waktu (fungsiolek) dan ragam kronologi (kronolek).

Ragam bahasa dapat juga dibedakan menurut media pengantar dan situasi pemakaian. Ragam bahasa berdasarkan sarana berbagi dapat dibedakan menjadi ragam lisan (ragam bahasa yang diujarkan oleh pemakai) dan ragam tulis (ragam bahasa yang tertulis atau tercetak). Ragam bahasa berdasarkan situasi pemakainya dapat dikelompokkan menjadi ragam formal dan ragam nonformal. Ragam bahasa formal adalah ragam bahasa yang dijadikan sebagai patokan untuk menentukan baik tidaknya sebuah kata dalam suatu bahasa, sedangkan ragam bahasa nonformal merupakan variasi bahasa yang tetap hidup dan terus berkembang sesuai dengan perkembangan zaman (Oktavia \& Hayati, 2020).

Menurut Sumarsono (2017) ragam bahasa formal merupakan variasi bahasa yang dengan sengaja disusun seusai dengan kaidah-kaidah konseptual dasar pada tataran fonologi, morfologi, sintaksis, semantik, logis maupun kosakata suatu bahasa dan digunakan untuk memenuhi suatu tujuan khusus. Berbeda dengan ragam bahasa formal, ragam bahasa nonformal merupakan variasi bahasa yang digunakan dalam situasi nonformal atau tidak resmi yang seringkali melanggar konseptual fonologi, morfologi, sintaksis, semantik, logis maupun kosakata dan dalam pemakaiannya sering ditemukan dalam ragam bahasa asing, sinonim, singkatan dan akronim.

\subsection{Teori Proses Pembentukan Kata (Word Formation Process)}

Santoso (2012) berpendapat bahwa proses pembentukan ragam bahasa, mulai dari pengambilan dan pembentukan kosakata dari bahasa asing menjadi sebuah istilah atau membentuk suatu satuan kata baru 
dengan suatu cara dilakukan secara alami tanpa adanya patokan atau aturan tertentu. Proses pembentukan kata baru ini mengakibatkan adanya ragam bahasa pada suatu bahasa tertentu. Bahasa Inggris merupakan salah satu bahasa asing yang paling banyak digunakan sebagai pembentuk istilah internasional. Bahasa Inggris memiliki berbagai macam proses pembentukan kata baru. Chaer (2008) menyatakan bahwa terdapat beberapa proses pembentukan kata dalam bahasa Inggris, yakni: afiksasi, compounding, akronim, borrowing, clipping dan blending.

Proses pembentukan kata dengan cara afiksasi merupakan proses pembentukan kata baru dengan cara memberikan imbuhan pada bentuk kata dasar, baik dalam bentuk dasar tunggal atau kompleks dan hasil dari proses pembentukan ini disebut dengan kata berimbuhan (Crystal, 2003). Dalam bahasa Inggris, proses afiksasi termasuk ke dalam proses morfologis yang sangat produktif karena bahasa Inggris tergolong dalam kelompok bahasa yang memiliki sistem aglutinasi. Sistem aglutinasi adalah proses pembentukan suatu kata yang dilakukan dengan cara menyisipkan atau menambahkan unsur lain pada unsur dasar suatu kata.

Compounding adalah proses pemajemukan kata dengan membentuk satuan kata baru dengan cara mnggabungan dua atau lebih kata lain yang berlaku sebagai satu unit yang menghasilkan kata majemuk (Wisnicwski, 2007). Compounding merupakan proses pembentukan kata yang sering ditemukan dalam bahasa Inggris. Kata-kata dalam bahasa Inggris, terutama kata sifat (adjective) dan kata benda (noun), dapat digabungkan dalam suatu konstruksi kata gabungan dengan berbagai macam dan cara. Keseluruhan makna dari sebuah kata majemuk dapat diprediksi dari makna tunggal dari setiap elemen. Akan tetapi, terdapat beberapa kata majemuk yang memiliki makna berbeda dan harus dipahami sebagai suatu kesatuan kata. 
Akronim adalah proses pembentukan kata baru yang terbentuk dari gabungan suatu kependekan kata dari huruf atau suku kata maupun elemen lain yang ditulis dan dapat dilafalkan sebagai satu kata yang wajar. Selain itu, akronim juga dapat diartikan sebagai singkatan dari suatu konsep yang direalisasikan dalam sebuah konstruksi kata (Chaer, 2008). Oktavia \& Hayati (2020) menyatakan bahwa proses akronimisasi dibentuk dengan mengindahkan keserasian kata dai berbagai susunan bunyi vokal dan konsonan yang sesuai dengan pola dan kaidah kata bahasa Indonesia. Adapun contoh akronim dalam bahasa Inggris adalah SAR (Search and Rescue) dan UNICEF (United Nation Children's Fund). Berbeda dengan akronim, singkatan merupakan proses pemendekan yang berupa huruf atau gabungan huruf, baik dalam cara bacanya dieja maupun tidak (Kridalaksana, 2010). Anbiya (2012) menjelaskan singkatan merupakan bentuk yang dipendekkan yang terdiri atas satu huruf atau lebih.

Borrowing merupakan suatu proses pembentukan kata baru dengan cara meminjam suatu kata leksikal yang berasal dari bahasa lain dan kemudian disesuaikan dengan kaidah bahasa sendiri. Hockett (1958) lebih rinci menjelaskan bahwa borrowing merupakan proses peminjaman atau penyerapan sebuah unit leksikal tunggal dari satu bahasa ke bahasa lain dan proses pembentukan kata ini akan melibatkan beberapa proses adaptasi dalam sistem ortografis, fonetik dan tata bahasa dari bahasa yang meminjam (Mesthrie, 2000). Adapun kata yang telah terbentuk dari proses ini disebut dengan loan word (kata pinjaman) yang sering ditemukan dalam ragam bahasa lisan maupun tulisan. Kata-kata pinjaman ini dapat mengalami perluasan makna, penyempitan makna, pembaharuan makna dan pemerosotan makna. Adapun contoh loan word dalam bahasa Inggris adalah kata entrepreneur (pengusaha) yang berasal dari bahasa Prancis, delicatessen (toko makanan) yang berasal dari bahasa Jerman, dan kata plaza (alun-alun) yang berasal dari bahasa Spanyol. 
Proses pembentukan kata dalam bahasa Inggris selanjutnya adalah clipping yang merupakan proses sebuah kata baru yang dibentuk dengan memperpendek suatu suku kata. Menurut Proses pembentukan kata baru ini dapat diklasifikasikan menjadi penggalan suku kata depan, penggalan suku kata belakang, penggalan suku kata kombinasi, penggalan suku kata depan dengan perubahan ejaan, penggalan nama orang, dan penggalan gabungan. Proses ini bertujuan untuk memudahkan pengucapan dan dieja daripada versi panjangnya karena proses ini cenderung untuk memendekkan kata-kata yang panjang. Adapun contoh clipped word dalam bahasa Inggris adalah sebagai berikut: kata ad berasal dari kata advertisement yang berarti iklan, kata lab merupakan versi pendek dari kata laboratory yang berarti laboratorium, dan kata typo merupakan versi pendek dari kata typhological error yang berarti kesalahan tulis.

Blending merupakan kata yang berasal dari hasil penggabungan dua bagian kata atau lebih yang digabungkan dan disusun secara bersamasama (Bauer, 1983). Berbeda dengan kata majemuk, proses ini menggunakan hanya sebagian dari kata yang digunakan untuk menyusun suatu kata baru. Makna dari kata tersebut merupakan kombinasi dari katakata pembentuknya. Blending sering ditemukan pada ragam bahasa nonformal. Adapun contoh kata dari proses pembentukan ini yang juga sering digunakan di Indonesia adalah istilah workaholic yang berasal dari kata work dan alcoholic yang berarti sebutan yang ditujukan kepada seseorang yang gila kerja dan istilah netizen yang berasal dari kata internet dan citizen yang berarti citizen internet (warga internet).

\section{Metode Penelitian}

Penelitian ini merupakan penelitian deskriptif kualitatif. Metode kualitatif digunakan dalam penelitian ini karena metode ini dinilai mampu menganalisa secara tepat dan mengkaji lebih dalam suatu fenomena 
kebahasaan. Penelitian deksriptif kualitatif merupakan penelitian yang memaparkan fenomena dan keadaan objek penelitian berdasarkan faktafakta sebagaimana adanya (Moelong, 2006). Penelitian ini secara khusus mengkaji dan mendeskripsikan proses pembentukan kata baru sebagai fenomena ragam bahasa istilah dalam iklan pariwisata di media digital pada masa pandemi COVID-19 ini. Teori yang digunakan pada penelitian ini adalah teori ragam bahasa oleh Chaer \& Agustina (2010) dan teori proses pembentukan kata oleh Chaer (2008). Instrumen penelitian ini adalah peneliti sendiri dan merupakan sebagai alat pengumpulan data utama.

Sumber data penelitian ini adalah iklan pariwisata di media digital. Pada proses pemerolehan data, pengumpulan data dilakukan dengan penjaringan dokumen dari beberapa sumber data tertulis di media digital yang telah dikumpulkan dengan teknik catat, yakni dengan melakukan pencatatan istilah-istilah baru yang digunakan dalam sumber data tersebut. Data yang telah dikumpulkan kemudian dianalisa berdasarkan pola karakteristik ragam bahasa yang membentuk istilah-istilah tersebut. Dalam menyajikan hasil analisis data, metode yang digunakan dalam penelitian ini adalam metode informal. Metode ini digunakan untuk mendeskripsikan dan memaparkan pola karakteristik serta proses pembentukan berbagai ragam bahasa istilah yang digunakan dalam iklan pariwisata di media digital selama masa pandemi COVID-19.

\section{Hasil dan Pembahasan}

Sejak ditetapkannya COVID-19 menjadi pandemi yang terjadi secara global, terdapat beberapa istilah khusus dalam bidang kesehatan atau medis yang kini menjadi istilah umum yang digunakan secara luas oleh masyarakat. Penggunaan istilah medis dalam bahasa asing lebih dominan ditemukan dibandingkan dengan istilah medis dalam bahasa 
Indonesia. Istilah-istilah medis seperti swab test (tes usab), rapid test (tes cepat) dan herd immunity (kekebalan kelompok) menjadi sering terdengar dan digunakan oleh masyarakat. Hal ini dikarenakan masyarakat secara terus-menurus membaca dan menonton tayangan di berbagai media yang menggunakan istilah-istilah medis tersebut.

Selain istilah dalam bidang kesehatan, terdapat beberapa istilah baru yang menggambarkan situasi dan kondisi masyarakat saat pandemi COVID-19. Adapun beberapa istilah baru seperti new normal era (era kenormalan baru), social distancing (jaga jarak), physical distancing (pembatasan fisik), isoman yang merupakan singkatan dari 'isolasi mandiri', menjadi sering terdengar dan digunakan oleh masyarakat secara luas. Tidak hanya pada kehidupan masyarakat sehari-hari, ragam istilah baru juga terjadi pada beberapa iklan pariwisata, terutama di media sosial seperti Facebook dan Instagram.

Dalam membuat sebuah iklan, bahasa merupakan salah satu elemen yang harus diperhatikan dan dipertimbangkan. Seorang penulis iklan harus mampu memilih bahasa yang tepat. Berdasarkan penelitian yang telah dilakukan, ditemukan beberapa istilah baru yang digunakan dalam iklan pariwisata. Jika dilihat dari media pengantarnya, ragam bahasa yang digunakan oleh pengiklan yakni ragam bahasa tulis karena iklan tersebut disebarluaskan dalam bentuk brosur digital. Berdasarkan tingkat formalitas, bahasa iklan cenderung menggunakan ragam bahasa nonformal karena dapat dilihat dari adanya ragam bahasa gaul dan ragam bahasa asing. Temuan data dalam bentuk istilah dalam iklan pariwisata di media digital berdasarkan proses pembentukan kata dan pola karakteristik ragam bahasa yang digunakan dapat dijelaskan sebagai berikut. 


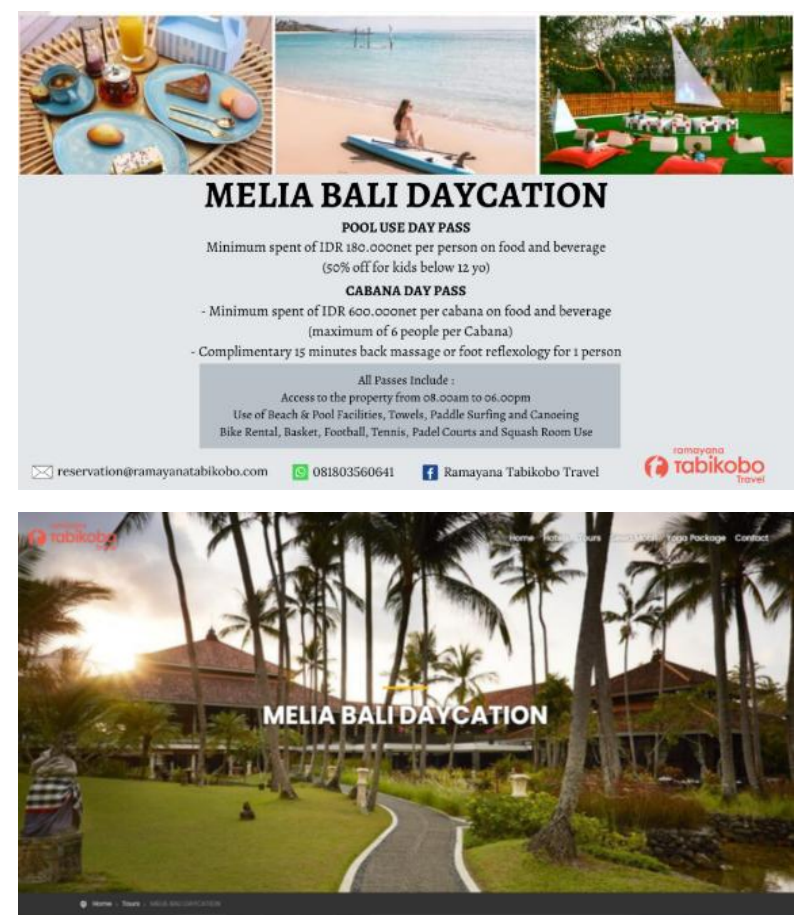

Gambar 1. Iklan Hotel di Media Digital di Masa Pandemi COVID-19 Sumber: https://ramayanatabikobo.com/tour/melia-bali-daycation/

Iklan pada Gambar 1 di atas menggunakan istilah daycation yang memiliki makna 'liburan satu hari'. Daycation merupakan sebuah kegiatan berlibur yang memiliki konsep meluangkan waktu satu hari untuk berlibur di daerah asalnya dan menghabiskan hari tersebut di dalam hotel, villa atau tempat menginap lainnya. Istilah daycation merupakan kata yang terentuk dari gabungan kata day (hari) dan vacation (liburan). Berdasarkan teori proses pembentukan kata, istilah ini terbentuk melalui proses blending yakni proses pembentukan kata baru yang terbentuk dari hasil penggabungan dari dua bagian kata atau lebih yang digabungkan dan disusun secara bersama-sama. 

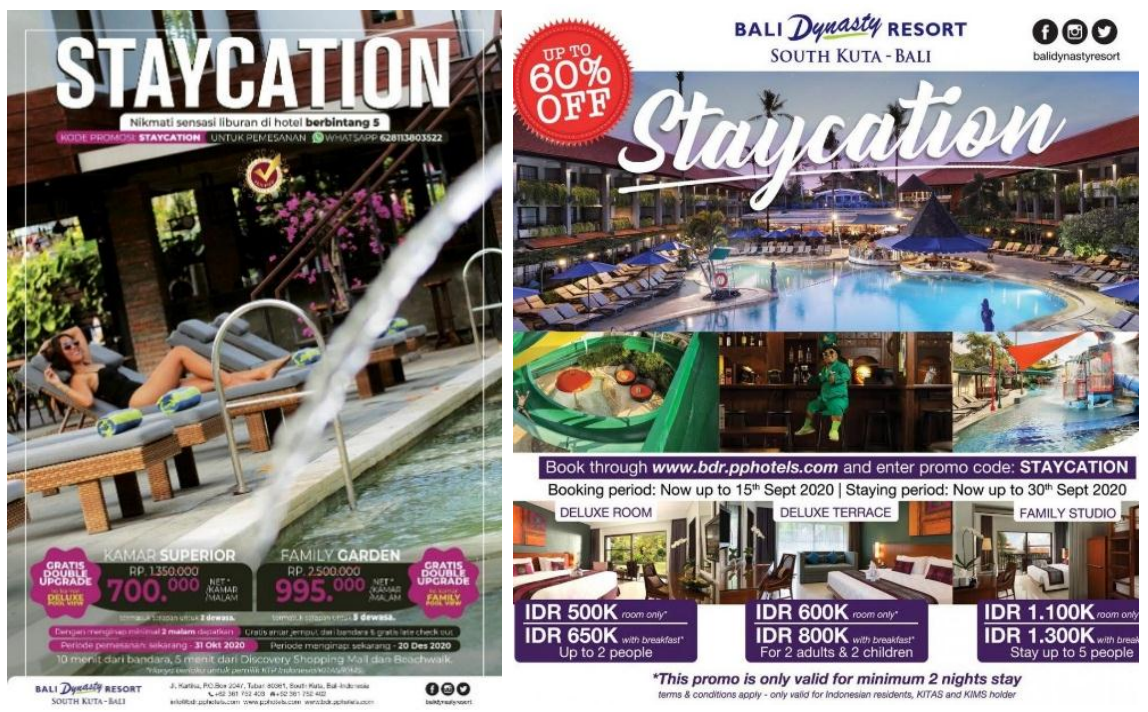

Gambar 2. Iklan Hotel di Media Digital di Masa Pandemi COVID-19 Sumber: https:/www.baliplus.com/2020/10/21/long-weekend-staycationdi-bali-dynasty-resort-kuta/

Berdasarkan iklan pada Gambar 2, ditemukan satu istilah baru dalam bahasa Inggris yang sama-sama digunakan untuk menarik khalayak menggunakan produk atau jasa pengiklan. Adapun istilah baru yang ada pada iklan tersebut adalah istilah staycation. Istilah staycation merupakan sebuah kegiatan berlibur yang memiliki konsep untuk melakukan semua kegiatan liburan di daerah asalnya dan menghabiskan waktu liburan di dalam hotel saja. Berdasarkan proses pembentukan kata, istilah staycation merupakan gabungan dari dua kata, yakni kata stay yang berarti tetap dan vacation yang berarti liburan. Proses ini dinamakan blending yakni proses penggabungan dari dua bagian kata atau lebih yang disusun secara bersama-sama dan membentuk satu kata baru dan memiliki arti dari kombinasi kata tersebut. 

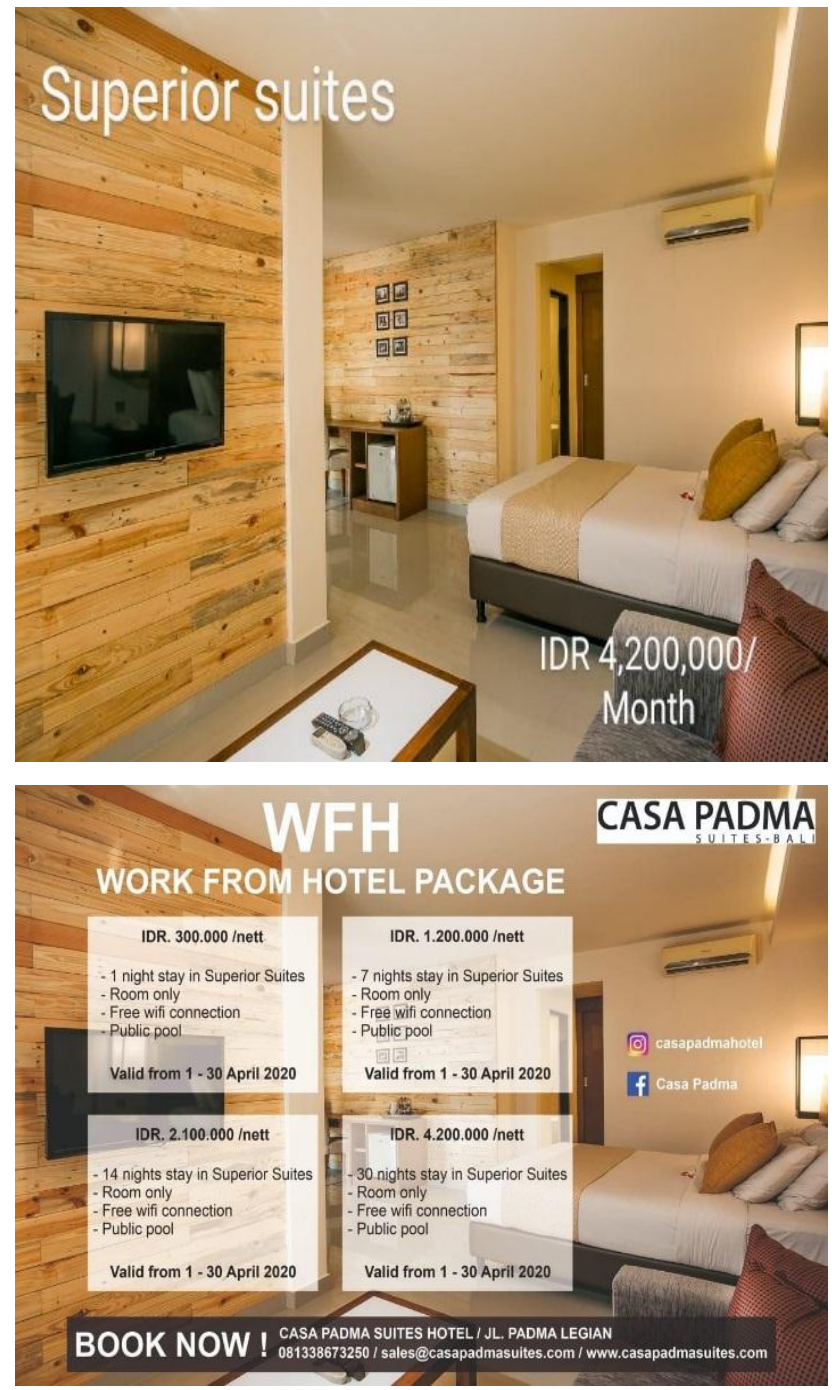

Gambar 3. Iklan Hotel di Media Digital di Masa Pandemi COVID-19 Sumber: https://www.facebook.com/pg/Casa-padma-suites-hotel-bali430276830645343/photos/

Berdasarkan Gambar 3 mengenai iklan hotel yang ditemukan pada media sosial Facebook, terdapat istilah WFH yang digunakan pada iklan tersebut. WFH merupakan singkatan dari kata work form home yang berarti 'bekerja dari rumah'. Jika dilihat dari proses pembentukannya, WFH merupakan sebuah singkatan yang terdiri atas huruf awal setiap kata 
dan ditulis dengan menggunakan huruf kapital. Singkatan ini terbentuk saat pandemi COVID-19 terjadi secara global dan mengharuskan masyarakat untuk tidak pergi ke kantor dan bekerja dari rumah. Saat pandemi COVID-19 melanda dunia, industri pariwisata, khususnya industri perhotelan, menggunakan singkatan WFH ini untuk mempromosikan produk atau jasa dalam menarik minat wisatawan. Namun, WFH yang digunakan dalam isndustri perhotelan megalami perubahan makna menjadi work form hotel atau 'bekerja dari hotel'.

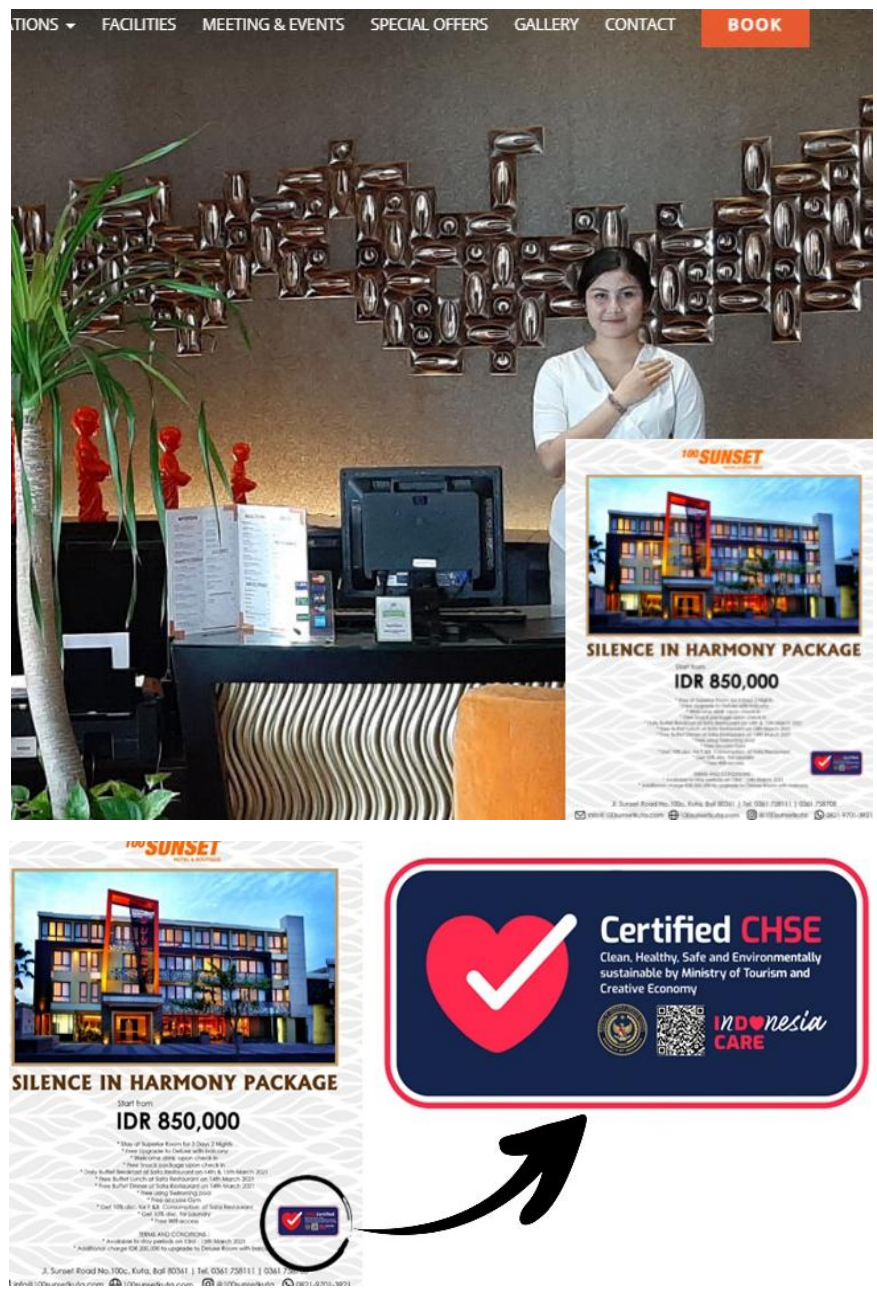

Gambar 4. Iklan Hotel di Media Digital di Masa Pandemi COVID-19 Sumber: https://100sunsetkuta.com/ 
Berdasarkan penelitian, selain singakatan WFH, ditemukan beberapa iklan pariwisata di media digital yang menyertakan sertifikasi CHSE. Sertifikasi ini merupakan sertifikasi yang diberikan kepada para pelaku usaha pariwisata di Indonesia oleh pemerintah Indonesia, khususnya Kementerian Pariwisata dan Ekonomi Kreatif / Badan Pariwisata dan Ekonomi Kreatif Republik Indonesia sejak dunia dilanda pandemi COVID-19. Sertifikasi ini bertujuan untuk memberikan jaminan kepada wisatawan terhadap pelaksanaan kebersihan, kesehatan, keselamatan, dan kelestarian lingkungan. Berdasarkan proses pembentukan kata, CHSE merupakan kata yang terbentuk dari proses singkatan. CHSE merupakan singkatan dari Clean, Healthy, Safe and Enviromentally Suistainable yang berarti 'bersih, sehat, aman dan ramah lingkungan'.

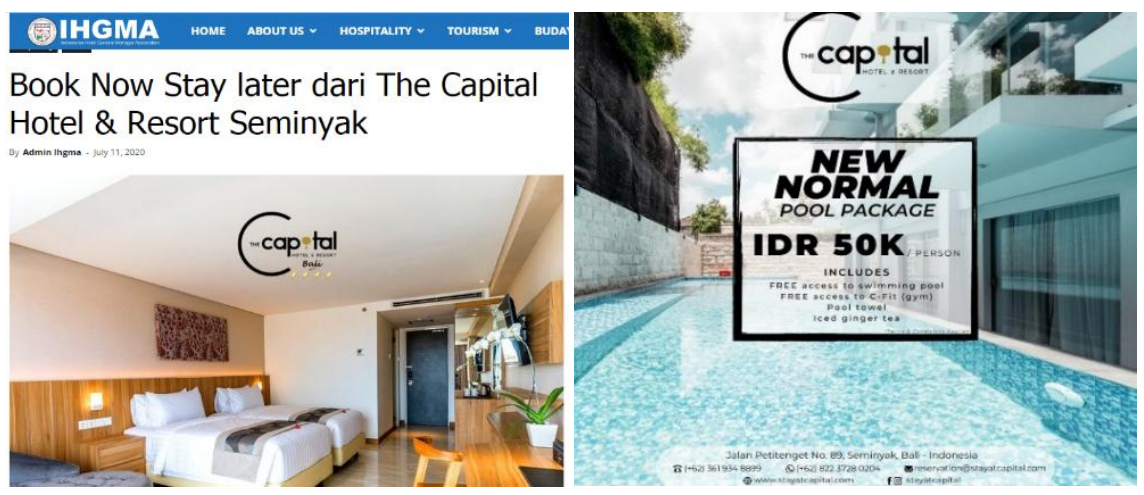

Gambar 5. Iklan Hotel di Media Digital di Masa Pandemi COVID-19 Sumber: https://www.ihgma.com/book-now-pay-later-dari-the-capitalhotel-resort-seminyak/

Berdasarkan iklan pariwisata pada Gambar 5, terdapat satu istilah baru yang digunakan untuk mempromosikan produk atau jasa pengiklan di industri pariwisata. Dalam iklan tersebut terdapat istilah new normal. Berdasarkan proses pembentukan kata, istilah new normal terbentuk dari proses compounding atau pemajemukan. Istilah new normal berasal dari 
dua kata sifat yakni new (adjektiva) dan normal (adjektiva), sehingga istilah tersebut termasuk jenis kata compound adjective yakni gabungan dari dua kata sifat yang membentuk makna baru. Istilah new normal memiliki makna sebagai ‘kenormalan baru’ yang mengacu pada pengertian perubahan budaya atau pola kehidupan baru.

\section{Simpulan dan Rekomendasi}

Berdasarkan hasil penelitian, dapat disimpulkan bahwa ragam bahasa yang digunakan dalam iklan pariwisata di masa pandemi COVID19 ini adalah ragam tulis jika dilihat dari media pengantarnya karena iklan tersebut disebarluaskan dalam bentuk brosur digital. Berdasarkan tingkat formalitas, bahasa iklan cenderung menggunakan ragam bahasa nonformal karena dapat dilihat dari adanya ragam bahasa gaul dan ragam bahasa asing. Jika dilihat dari proses pembentukan ragam istilah yang digunakan pada iklan pariwisata di media digital pada masa pandemi COVID-19 ialah blending seperti pada istilah staycation dan daycation, singkatan seperti pada istilah WFH dan CHSE serta istilah new normal yang terbentuk dari proses compounding.

\section{Daftar Pustaka}

Alwi, H, dkk. (2003). Tata Bahasa Baku Bahasa Indonesia. Jakarta: Balai Pustaka

Anbiya, F.P. (2012). Panduan EYD Saku. Jakarta: TransMedia

Bauer, L. (1983). English Word-formation. Cambridge: Cambridge University Press.

Chaer, A. (2008). Morfologi Bahasa Indonesia (Pendekatan Proses). Jakarta: Rineka Cipta

Chaer, A \& Agustina, L. (2010). Sosiolinguistik: Perkenalan Awal. Jakarta: Rineka Cipta

Crystal, D. (2003). The Cambridge Encyclopedia of the English Language. Cambridge University Press

Goddard, A. (2002). The Language of Advertising. London: Routledge Hockett, C.F. (1958). A Course in Modern Linguistics. New York: MacMillan Company 
Holmes, J. (2001). An Introduction to Sociolinguistics (2 ${ }^{\text {nd }}$ Edition). London: Longman

Kridalaksana, H. (1993). Kamus Linguistik. Jakarta: PT. Gramedia Pustaka Utama (2010). Pembentukan Kata dalam Bahasa Indonesia. Jakarta: PT. Gramedia Pustaka Utama

Kriyantono, R. (2008). Teknis Praktis Riset Komunikiasi. Jakarta: Kencana Predana Media Group

Mesthrie, R. et al. (2000). Introducing Sociolinguistics. Edinburgh: Edinburgh University Press.

Moleong, L. (2006). Metode Penelitian Kualitatif. Bandung: PT. Remaja Rosdakarya

Nababan, P.W.J. (1984). Sosiolinguistik: Suatu Pengantar. Jakarta: PT. Gramedia Pustaka Utama

Oktavia, W. (2018). "Variasi Jargon Chatting Whatsapp Grup Mahasiswa Tadris Bahasa Indonesia". Jurnal Kata, 2(2), 317-325

Oktavia, W. \& Hayati, Nur. (2020). "Pola Karakeristik Ragam Bahasa Isntilah pada Masa Pandemi Covid 19 (Coronavirus Disease 2019)". Tabasa: Jurnal Bahasa, Sastra, dan Pengajarannya. Vol. 1, No. 1, Juni 2020 3-15 https://ejournal.iainsurakarta.ac.id/ index.php/tabasa/article/view/2607

Pratiwi, D.E. (2016). "Bahasa Kias pada Iklan TV". SPHOTA Volume 8, No. 2, 1-9

Rahardi, R.J. (2006). Dimensi-Dimensi Kebahasaan: Aneka Masalah Bahasa Indonesia Terkini. Jakarta: Erlangga

Santoso, I. (2012). "Pendidikan Karakter dan Pembelajaran Bahasa Asing Berwawasan Interkultural". Jurnal Pendidikan Karakter, 2(1), 96106 https://journal.uny.ac.id/index.php/jpka/article/view/1455

Soeparno. (2002). Dasar-Dasar Linguistik. Yogyakarta: Tiara Wacana Sudaryanto. (1993). Metode dan Aneka Teknik Analisis Bahasa. Yogyakarta: Duta Wacana University Press.

Sumarsono. (2017). Sosiolinguistik. Yogyakarta: Pustaka Pelajar Suwardjono. (2004). Pedoman Umum Pembentukan Istilah (PUPI). Departemen Pendidikan dan Kebudayaan Balai Pustaka

Suwarna. (2002). Strategi Pengantar Berbahasa. Yogyakarta: Adicita Karya Nusa.

Thorne, S.L. \& Lantolf, J.P. (2006). A Linguistics of Communicative Activity. U.K.: Multilingual Matters

Wiratno, T. (2018). Pengantar Rigkas Linguistik Sistemik Fungsional. Yogyakarta: Pustaka Pelajar

Wisniewski, K. (2007). "Word Formation". http://www.tlumaczeniaangielski.info/linguistics/word-formation.htm 


\section{Profil Penulis}

Ni Putu Cahyani Putri Utami, S.S., M.Hum., lahir di Denpasar, 25 Maret 1992. Menempuh pendidikan S1 di Sekolah Tinggi Bahasa Asing (STIBA) Saraswati Denpasar dan S2 di Universitas Udayana. Saat ini penulis merupakan dosen di Fakultas Bahasa Asing, Universitas Mahasaraswati. 